\title{
BEACH LITTER AND GRADING OF THE COASTAL LANDSCAPE FOR TOURISM DEVELOPMENT IN SECTIONS OF GUYANA'S COAST
}

\author{
Oyedotun, T. D. T.*, Johnson-Bhola, L \\ Department of Geography, Faculty of Earth and Environmental Sciences, University of Guyana, P. OBox 10 1110, Turkeyen Campus, Greater \\ Georgetown, Guyana, South America. \\ *Corresponding author email: oyedotuntim@yahoo.com; temitope.oyedotun@uog.edu.gy
}

This is an open access article distributed under the Creative Commons Attribution License, which permits unrestricted use, distribution, and reproduction in any medium, provided the original work is properly cited.

\section{ARTICLE DETAILS}

\section{Article History:}

Received 2 October 2018 Accepted 5 November 2018 Available online 18 February 2019

\section{ABSTRACT}

Beach litter constitutes one of the glaring signs of pollution in coastal landscape and environment. In this study, litter presence and composition were assessed for the five (5) sampling sites along the coastline in three (3) Administrative Regions (Regions 4, 5, and 6) in Guyana based on fieldwork carried out in January 2018. Survey of beach litters represents a fundamental, standard, and documented tool for monitoring pollution in a coastal environment and this method was used in evaluating, classifying, and quantifying the composition of beach litters along the five (5) sites aforementioned. This study showed that the litter contents varied considerable among the sampling sites. However, out of all the categories of beach litter items in all of the sample sites, plastic materials accounted for most of the litter followed by metal, paper/card, glass, wood fragments, clothing materials, organic materials, and pottery at $48.2 \%, 20.8 \%, 11.5 \%, 6.8 \%, 4.7 \%, 4.6 \%, 3.2 \%$, and $0.2 \%$ respectively. The average grading of the beaches shows that none could be graded A (very good), without cleaning up of such areas of litter. Rosignol beach (Sample Site 3) and Georgetown beach (Sample Site 5) were the only beaches with average grade C (fair) while the other three (3) samples sites could only be graded D, very poor. This paper highlights the geographic distribution, pattern, and litter composition in the study areas. To meet the demands of the potential beach users for the purpose of coastal tourism and to benefit from the growing "sun, sea, and sand (3S)" industry, conscious and strategic Beach Litter Management and Monitoring, among other recommendations, is suggested in this study.

\section{KEYWORDS}

Litter; beach areas; coastal tourism; marine pollution.

\section{INTRODUCTION}

Coastal zones of the world have served as vital sources of many valuable resources for satisfying man's varied socio-economic and recreational needs. This dynamic natural region, where the linkage between water and land is most prominent, has become a magnet of attraction for infrastructural development, concentration of industries, and fascination of the human population. Over 40 percent of the global population resides within the $100 \mathrm{~km}$ distance from the coastal shorelines, making the zones areas of highest population density [1]. Coastal tourism has also commanded high world-wide attention, thereby making it one of the world's largest industries [2,3]. Tourists and recreational visitors are mostly attracted to beaches; making the condition of beaches area a major factor in the tourism market/industry and determination of tourists' preferences [4-6].

The growing capacity of coastal tourism in the Caribbean coastal areas is reflected in the number of tourist arrivals and contribution to GDP and GNP of the host countries. The number of international travels between 2007 and 2015 continued to be high, with a combined total of 2,441,033 coastal tourists' arrivals for the period from Canada, USA, UK, and the European Union. Added to this is the sum of approximately 4,000,000 domestic arrivals from the CARRICOM countries [3,5,7]. Visitors of these nations are especially interested in the coastal tourism package [2]. The growing interests of tourists have contributed immensely to the Gross Domestic Product (GDP) and Gross National Product (GNP) of most of the host nations, with this industry being a source of foreign exchange earnings [4]. For example, tourism contributed approximately US $\$ 270$ million per year to Colombia's GDP [8] and about US\$ 60 billion to Spain's GDP as well $[9,10]$.
In an effort to take advantage of the growing global coastal tourism industry, many Caribbean countries have consciously and deliberately developed policies and proactive programmes for their coastal areas and these have resulted in astronomical growth in their share of global visitors in the last decade [2,10-13]. One such policy is 'keeping the beaches clean' $[14,15]$. The main challenge to the utilisation of beaches in the region is the degradation of this dynamic environment through beach littering, dumping of wastes, and pollution $[3,5,16,17]$. Studies which focus on the spatial distribution of the beach litters [18-21], the examination of beach litter composition [22-24], the perception of beach users/tourists [25, 26], and sources of beach litters $[6,27-30$,$] show that there is a positive$ correlation between beach aesthetics and enthusiasm of tourists. Apart from these scholarly works on beach litters, some nations have recent information on their marine debris and beach litter over wide areas of their coastline. Good examples of these countries are Spain [3], Colombia [5], Chile[31], Wales [32], Australia [33], Slovenia [34], and Cuba $(13,6]$.

Marine/beach litter, here, is defined as "any persistent, manufactured or processed solid material discarded, disposed of, or abandoned in the marine and coastal environment" (CBD Technical Series, [34] cited in [35]. Survey of beach litter presence in all compartments of coastal environments, especially at intertidal coastal zone and beach areas [36] with the aim of qualifying, classifying, and quantifying the litter - is a very fundamental step in monitoring the weight of the litter [37] and it is a key factor in strategizing how to minimise the presence of this load in the coastal environment [38].

Guyana, a developing country, is conspicuously not one of the countries that benefitted significantly from over 23.8 million visitors to the Caribbean and the Southern America in 2015 [10]. Some coastal areas 
have huge potential to benefit from the growing tourism industry. Within the context of scientific literature or national database, however, research about Guyana's beach litter is either non-existence or scarce. To explore the possibilities of developing the investigated areas for coastal tourism, several actions are needed. Survey carried out and presented in this paper provides the first step in the characterisation of beach litter at five (5) areas along the coastline. This paper, therefore, provides the baseline on beach litter in some sections of Guyana's coastline. The intent was to examine the characteristics of beach litter and its impact on the socioeconomic, cultural, and environmental opportunities of this region. It is hoped that the results presented here as well as the discussion provided will be highly useful to local, regional, and national coastal managers/planners who may need the inventory for sound management decisions and serve as benchmark for similar studies in other developing countries.

\section{MATERIALS AND METHODS}

\subsection{The Study Area - Guyana Coastline}

About 90 percent of Guyana's 750,000 population occupies the nation's coastal strip, thereby making this strip highly valuable in the context of the socio-economic, administrative, and diverse anthropogenic significance and influence $[39,40]$. The investigated areas include five (5) beaches from three regions (Regions 4, 5, and 6) of the $\sim 430 \mathrm{~km}$ coastline (Fig. 1). This Coastal Plain, characterised by relatively mild meteorological and hydrological conditions [41], extends from the Waini River in the North to the Corentyne River in the South. It consists of different sections or subdivisions demarcated by a number of river mouths (specifically the Pomeroon, Essequibo, Demerara, Mahaica, Mahaicony, Abary, and Berbice Rivers) $[39,42]$. Apart from being below sea-level at mean high tide, this coastline has a unique problem of huge sediment load (specifically high mud supply consisting of sediment input from the Amazon, Essequibo, and Oronoco $[43,44]$ in many sections, which has limited the of number areas with sandy beaches and has also subjected the nearshore zone to the migrating mud shoals $(45,46]$. Guyana's coast lies predominantly in a northwest-southeast orientation and is influenced by northeast Trade Winds which vary between $5 \mathrm{~m} \mathrm{~s}^{-1}$ and $10 \mathrm{~m} \mathrm{~s}^{-1}$, a low wave height between $1 \mathrm{~m}$ and $2 \mathrm{~m}$, and a semi-diurnal tidal range between $1.5 \mathrm{~m}$ and $2.5 \mathrm{~m}[41,47,48]$.

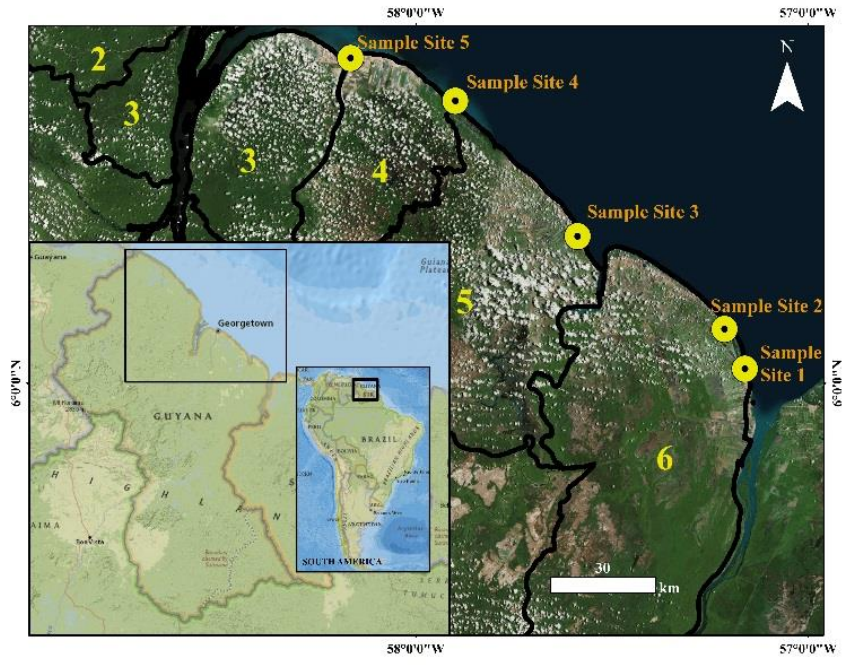

Figure 1: Location of the Study Area (Inset: South America showing the location of Guyana and Map of Guyana showing the nation's capital and the coastal areas studied. Data Sources: National Geographic, Esri, Garmin, HERE, UNEP-WCMC, USGS, NASA, ESA, METI, NRCAN, GEBCO, NOAA, increment P Corp. Credit: Content may not reflect National Geographic's current map policy. Imagery Source: Esri, DigitalGlobe, GeoEye, Earthstar Geographics, CNES/Airbus DS, USDA, USGS, AeroGRID, IGN, and the GIS User Community)
Table 1 Samples Sites location and their corresponding regions

\begin{tabular}{|c|c|c|}
\hline Sample Site & Location & Region \\
\hline 1 & Corriverton & 6 \\
\hline 2 & No. 63 Beach & 6 \\
\hline 3 & Rosignol & 5 \\
\hline 4 & Mahaicony & 4 \\
\hline 5 & & 4 \\
\hline
\end{tabular}

\subsection{Beach Surveys}

Five beaches (See Figure 1) were surveyed at low tide during the four weekends of January 2018. The litter items found between the landward boundary - which is usually the seawall - and the low water shoreline at a $20 \mathrm{~m}$ by $20 \mathrm{~m}$ beach transect width were categorized and recorded for this study. The methodology adopted here follow the EA/NALG [49] method of sample selection, litter classification, and evaluation. Low water shoreline/strandline and landward boundary are mostly used for recreational/tourism activities and these areas of coastline have remained the focal points of waste and litter concentration and evaluation $[3,5,32,50$,$] . From previously published works, there are approximately$ 183 categories of litter common in beach areas based on their material composition and sizes $[3,49,51-56]$ out of which 43 categories were present in the five (5) sites surveyed (Table 1).

In this study, the backshore boundary here represents either the dune foot, the vegetation line, or anthropogenic structures like seawalls, fences, and roads. The backshore boundary here represents either the dune foot, the vegetation line, or anthropogenic structures like seawalls, fences, and roads. Beach surface litters were captured at the 'sampling unit' following the method of Rangel-Buitrago [17]. In the first instance, the photographic evidence of the beach debris and litters of every sampling unit at the study sites was captured in scenes in each of the grid squares during the field exercise [49]. The second step taken was the identification of beach debris and litters as captured in the photographic scenes; itemizing, counting, and rating of the litters, in a bid to present the number of litter items per sampled areas. The last step was the classification of litters following the guidelines of MSFD Technical Sub-group on Marine Litter [57,35].

\subsection{Beach gradings}

The five (5) sampled sites (Table 1, Figure 1), which represent the five beach areas along the coastline, shortlisted for this study were evaluated and graded on a scale of "Very Good" to "Poor" (which represent the Grades A to D in EA/NALG respectively, Table 3). The focus of this aspect of investigation is to provide the summarised status of the beaches that can guide the coastal/beach managers in evaluating the severity of these litter impacts at the sample sites. This method enables the grading of the beach based on selected categories aforementioned, Table 3 . 
Table 2: EA/NALG Beach grading system based on selected categories of litter [49]. Grading: A Very good; B Good; C Fair, D Poor

\begin{tabular}{|c|c|c|c|c|c|c|}
\hline Category & Type & Feature Items & $\mathbf{A}$ & B & C & D \\
\hline Sewage & General & $\begin{array}{l}\text { Feminine hygiene products (sanitary } \\
\text { towels, tampons and applicators, } \\
\text { contraceptives, toilet paper, excrement } \\
\text { of human origin). }\end{array}$ & 0 & $1-5$ & $6-4$ & $15+$ \\
\hline Related debris & Cotton buds & $\begin{array}{l}\text { Cotton bud sticks }- \text { harmless in } \\
\text { themselves but they denote a sewage } \\
\text { input }\end{array}$ & $0-9$ & $10-49$ & $50-99$ & $100+$ \\
\hline Gross litter & e.g. Tyres & $\begin{array}{l}\text { Gross litter } \\
\text { (at least one dimension }>50 \mathrm{~cm} \text { ) - } \\
\text { include: shopping trolleys, pieces of } \\
\text { furniture, road } \\
\text { cones, large plastic or metal containers; } \\
\text { bicycles, prams; tyres; and large items } \\
\text { of processed } \\
\text { wood e.g. pallets. Driftwood is not } \\
\text { included. }\end{array}$ & 0 & $1-5$ & $6-14$ & $15+$ \\
\hline General Litter & e.g. bottles & $\begin{array}{l}\text { General litter (all other items }<50 \mathrm{~cm} \\
\text { in dimension) - includes: drink cans, } \\
\text { food packaging, cigarette packets, etc }\end{array}$ & $0-49$ & $50-499$ & $500-999$ & $1000+$ \\
\hline Harmful litter & $\begin{array}{l}\text { Broken glass } \\
\text { Others }\end{array}$ & $\begin{array}{l}\text { Potentially } \\
\text { harmful litter (dangerous to either } \\
\text { humans or animals using the beach) - } \\
\text { includes: } \\
\text { sharp broken glass (counted as a } \\
\text { separate category), medical waste (e.g. } \\
\text { used syringes), } \\
\text { colostomy bag, sharps (metal wastes, } \\
\text { barbed wire, etc.), soiled disposable } \\
\text { nappies, containers marked } \\
\text { as containing toxic products, other } \\
\text { dangerous products such as flares, } \\
\text { ammunition } \\
\text { and explosives ammunition and dead } \\
\text { domestic animals. }\end{array}$ & 0 & $1-5$ & $\begin{array}{l}6-24 \\
5-9\end{array}$ & $25+$ \\
\hline Accumulations & Number & $\begin{array}{l}\text { Accumulations of litter } \\
\text { - discrete aggregations of litter clearly } \\
\text { visible from a distance; either blown by } \\
\text { the wind or } \\
\text { dumped by users of the beach, often in } \\
\text { the highwater strandline among } \\
\text { seaweed. }\end{array}$ & 0 & $1+4$ & $5-9$ & $10+$ \\
\hline Oil & & $\begin{array}{l}\text { Oil and } \\
\text { other oil-like substances }- \text { all oil } \\
\text { waste (mineral or vegetable), either } \\
\text { from fresh oil spills } \\
\text { or the presence of weathered oil } \\
\text { deposits and tarry wastes. }\end{array}$ & Absent & Trace & Nuisance & Objectionable \\
\hline Excrement & & $\begin{array}{l}\text { Excrement (non-human) - dogs } \\
\text { (sheep or horse faeces are not being } \\
\text { counted). }\end{array}$ & 0 & $1-5$ & $6-24$ & $25+$ \\
\hline
\end{tabular}

\section{RESULTS AND DISCUSSION}

\subsection{Beach litters}

From the field investigation, all of the sampling sites had at least one litter. Table 3 records and itemises the different litter items found in each of the sampling sites. Plastic or rubber materials accounted for $48.2 \%$ of the litters, followed by metal at $20.8 \%$, paper/card at $11.5 \%$, glass at $6.8 \%$, wood fragments at $4.7 \%$, clothing materials at $4.6 \%$, organic materials at $3.2 \%$, and pottery at $0.3 \%$ (Figure 2). However, the litter contents varied considerably from site to site, with the greatest abundance of clothing material (in terms of number of items identified in each sample site) observed at Site 2 in No. 63 Beach at $34.6 \%$ of all the clothing and other related materials found in the coastal/beach areas. This is followed by the sample Site 5 (at Georgetown) at 28.5\%, Site 1 at $16.9 \%$, and Sites 3 and 4 at $10 \%$ each (Table 3 and Figure 3 ). Similarly, the litter composition of glass materials expressed as percentages with respect to the quantity of the surveyed items at the sampling sites (Figure 3) also indicate that the sites with highest percentage are No. 63 Beach (Site 2), Georgetown (Site 5), and Corriverton (Site 1) at 39.2\%, 25.9\%, and 16.4\% respectively. Litter materials made of metals (e.g. drink cans, foil wrappers, food cans, and oil drums) were also highly concentrated in samples Site 2, 3, and 5 at $30.1 \%, 30 \%$, and $20.5 \%$ respectively (Figure 3). Of sizeable litter composition in all the sampling sites were materials made of plastic or rubber, for example shopping bags, drink bottles, and plastic cups (see Table 2 for the full list). Out of all the 1350 items identified in all of the five sampling sites, $30.6 \%$ of these were observed at Site $2,25.2 \%$ at Site 3 , and $21.8 \%$ at Site 5 representing the highest concentration/composition of this category of litters in the beach areas of the study sites. Other litter materials identified (i.e. paper/card; pottery, organic and wood fragments) also have different compositions in each of the sampling sites. Table 3 presents the total number of items identified while Figure 3 presents their percentage frequency per site. 
Table 2: Composition of litters found in sampled location along the beach area of Guyana coastline

\begin{tabular}{|c|c|c|c|c|c|c|c|c|}
\hline \multicolumn{2}{|c|}{ Litre Items surveyed } & \multicolumn{7}{|c|}{ Total Number of Items per sampled sites } \\
\hline Material & Description & Site 1 & Site 2 & Site 3 & Site 4 & Site 5 & Total & $\begin{array}{l}\text { Material } \\
\text { Totals } \\
\end{array}$ \\
\hline \multirow{4}{*}{ Cloth } & Shoes (leather) & 6 & 14 & 1 & 3 & 15 & 39 & \\
\hline & $\begin{array}{ll}\text { Sanitary } & \text { towels/panty } \\
\text { liners/backing strips } & \\
\end{array}$ & 8 & 11 & 4 & 7 & 9 & 39 & \\
\hline & Toilet fresheners & 4 & 7 & 3 & 1 & 5 & 20 & \\
\hline & Cloth (General Textiles) & 4 & 13 & 5 & 2 & 8 & 32 & 130 \\
\hline \multirow[t]{3}{*}{ Glass } & Beverage bottles & 12 & 38 & 12 & 6 & 24 & 92 & \\
\hline & Jars & 2 & 7 & 2 & 2 & 7 & 20 & \\
\hline & Glass fragments $2.5 \mathrm{~cm}-50 \mathrm{~cm}$ & 17 & 29 & 11 & 2 & 18 & 77 & 189 \\
\hline \multirow[t]{7}{*}{ Metal } & Drink cans & 23 & 76 & 69 & 12 & 48 & 228 & \\
\hline & Foil wrappers & 29 & 71 & 57 & 9 & 29 & 195 & \\
\hline & Food cans & 8 & 6 & 37 & 3 & 15 & 69 & \\
\hline & Oil drums & 2 & 2 & 1 & 0 & 2 & 7 & \\
\hline & Lobster/crab pots and tops & 2 & 5 & 7 & 2 & 4 & 20 & \\
\hline & Batteries & 3 & 4 & 3 & 1 & 4 & 15 & \\
\hline & Metal fragments $>50 \mathrm{~cm}$ & 11 & 14 & 3 & 2 & 17 & 47 & 581 \\
\hline \multirow[t]{4}{*}{ Organic } & Dog excrement & 5 & 8 & 3 & 2 & 7 & 25 & \\
\hline & Food residues & 3 & 12 & 9 & 2 & 17 & 43 & \\
\hline & Fish apparel & 0 & 3 & 2 & 2 & 3 & 10 & \\
\hline & Animal carcases/ dead animals/pets & 2 & 3 & 3 & 1 & 2 & 11 & 89 \\
\hline \multirow[t]{4}{*}{ Paper/card } & Cardboard & 7 & 12 & 6 & 1 & 8 & 34 & \\
\hline & Cigarette packets & 12 & 34 & 19 & 6 & 18 & 89 & \\
\hline & $\begin{array}{l}\text { Paper (including newspapers \& } \\
\text { magazines) }\end{array}$ & 17 & 53 & 11 & 0 & 57 & 138 & \\
\hline & Cartons e.g. tetrapak (other) & 13 & 28 & 9 & 3 & 7 & 60 & 321 \\
\hline \multirow[t]{15}{*}{ Plastic/Rubber } & Bags (e.g. Shopping) & 22 & 47 & 26 & 4 & 17 & 116 & \\
\hline & $\begin{array}{l}\text { Drinks (bottles, containers and } \\
\text { drums) }<2 \mathrm{~L}\end{array}$ & 19 & 33 & 19 & 8 & 16 & 95 & \\
\hline & $\begin{array}{l}\text { Cleaner (bottles, containers and } \\
\text { drums) }<2 \mathrm{~L}\end{array}$ & 21 & 29 & 11 & 6 & 23 & 90 & \\
\hline & Engine oil containers and drums & 6 & 13 & 2 & 1 & 9 & 31 & \\
\hline & Knives, forks, & 14 & 26 & 35 & 8 & 39 & 122 & \\
\hline & Straws & 27 & 51 & 58 & 12 & 31 & 179 & \\
\hline & $\begin{array}{l}\text { Hard/Foamed plastic food } \\
\text { containers (fast food, glasses, tops, } \\
\text { lunch boxes \& similar) }\end{array}$ & 13 & 45 & 64 & 3 & 23 & 148 & \\
\hline & Cigarettes, butts, filters, and lighters & 31 & 42 & 47 & 12 & 37 & 169 & \\
\hline & Hard plastic cups & 3 & 12 & 8 & 1 & 11 & 35 & \\
\hline & Toys \& party poppers & 4 & 14 & 21 & 0 & 8 & 47 & \\
\hline & Rope (diameter more than $1 \mathrm{~cm}$ ) & 8 & 16 & 3 & 7 & 15 & 49 & \\
\hline & Fish boxes & 2 & 7 & 5 & 4 & 6 & 24 & \\
\hline & Fishing line (angling) & 4 & 7 & 2 & 7 & 8 & 28 & \\
\hline & Floats/buoys & 1 & 3 & 1 & 1 & 4 & 10 & \\
\hline & $\begin{array}{l}\text { Industrial packaging, } \\
\text { sheeting, } \\
\text { palette wrap, tarpaulin, woven }\end{array}$ & 23 & 44 & 26 & 6 & 31 & 130 & \\
\hline
\end{tabular}




\begin{tabular}{|l|l|l|l|l|l|l|l|l|}
\hline & plastic bags & & & & & & & \\
& & & & & & & \\
& & 3 & 6 & 4 & 1 & 5 & $\mathbf{1 9}$ & \\
\hline & Shoes/sandals & 2 & 4 & 1 & 4 & 3 & $\mathbf{1 4}$ & \\
\hline & Nets and pieces of net & 1 & 2 & 2 & 0 & 1 & $\mathbf{6}$ & \\
\hline & Boots & 9 & 6 & 3 & 1 & 2 & $\mathbf{2 1}$ & \\
\hline & Tyres and belts & 3 & 6 & 2 & 0 & 6 & $\mathbf{1 7}$ & $\mathbf{1 3 5 0}$ \\
\hline & Gloves & & & & & & & \\
\hline & & 1 & 3 & 1 & 0 & 3 & $\mathbf{8}$ & $\mathbf{8}$ \\
\hline & Ceramic fragments 2.5 cm-50 cm & & & & & & & \\
\hline Wood & & 73 & 22 & 12 & 11 & 14 & $\mathbf{1 3 2}$ & $\mathbf{1 3 2}$ \\
\hline & Wood fragments & $\mathbf{4 8 0}$ & $\mathbf{8 8 8}$ & $\mathbf{6 3 0}$ & $\mathbf{1 6 6}$ & $\mathbf{6 3 6}$ & $\mathbf{2 8 0 0}$ & $\mathbf{2 8 0 0}$ \\
\hline
\end{tabular}

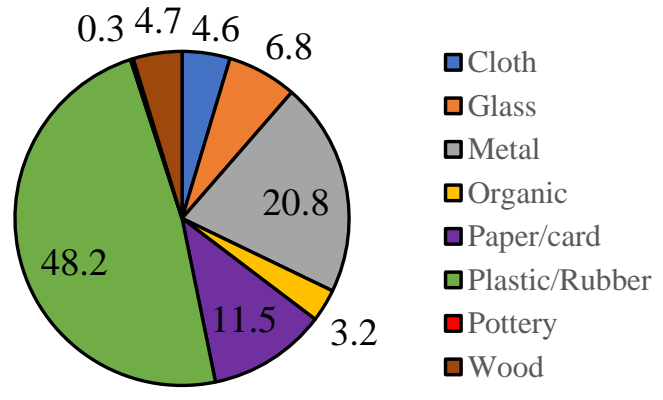

Figure 2: Percentage of beach litter composition in all the sampled sites

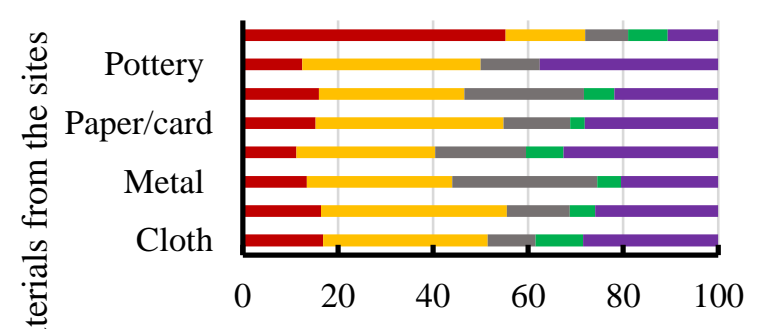

Comparison of Percentage of Composition (\%)

- Site $1 \square$ Site $2 \square$ Site 3

Figure 3: Comparing the percentage of material composition in each of the sites sampled for this study.

The items observed in the survey correspond to what has been observed in other previous studies $[17,35,57]$. The highest concentration of litter in all the study sites was plastic items, which are land-based materials. The findings here are supported by those from other related studies in developed countries and developing countries. For example, the documented work by a group of researchers in Central Italy, findings in Japan, and results of South China Sea investigations, among others linked the source of litter in beach areas to sources from land $[19,20,58]$. Other recent works on anthropogenic marine debris in the coastal environment of Chile, on the plastics and microplastics on recreational beaches of Punta del Este in Uruguay and studies from South East Pacific and Columbia all confirmed that most of the abundant of litters found along the beach and coastal areas of the world are plastics generated from the land, with their daily quantity entering these areas being relatively unknown[17,59-61]. However, the other researchers estimated the plastic litter being generated as wastes that end up in the coastal areas of Columbia reaching the "values of 1,075,294 kg day-1" [17].

Of all the plastic items observed in the five (5) beach areas surveyed, plastic fragments, plastic bags (shopping bags), and plastic bottles constituted the perennial presence in all the sites. These also confirm the findings in other parts of the world that the fragments are the most frequently occurring items in many of the world's coastal areas. Examples of these are found in the UK and Spain $[51,62]$.
Apart from the dominance of plastic materials at the sampled locations, metal and glass pieces were also of sizeable amounts. This is not peculiar to Guyana's coastal areas alone. Abundance of glass and metal materials has also been documented in other coastal environments, for example in some Australian beaches $[63,64]$.

\subsection{Grading of the beaches}

The litter grading and coastal scenic evaluation of sample sites along the beach areas of this coastline were examined using the EA/NALG guide[49]. Table 4 presents the summary of the evaluation of each of these sample sites. The beach at Corriverton (sample Site 1) had many general sewage and litters; accumulation of harmful litters, deposit of plastic bottles, countless wood fragments, silver pipes, baby's diapers, oil, and excrement, among other materials (Figure 4). Based on the EA/NALG guide and field coastal scenic evaluation, this beach can be graded D, that is, poor. The beach will need clean-up before it could be used for recreational or tourism purposes [49].

Table 3: The Grading of Sample beaches using the EA/NALG (2000) guide

\begin{tabular}{|l|l|l|l|l|l|l|}
\hline Category & Type/Sites & $\mathbf{1}$ & $\mathbf{2}$ & $\mathbf{3}$ & $\mathbf{4}$ & $\mathbf{5}$ \\
\hline Sewage & General & C & C & B & C & C \\
\hline Related debris & $\begin{array}{l}\text { Cotton } \\
\text { buds, etc }\end{array}$ & A & B & A & A & A \\
\hline Gross litter & e.g. Tyres & C & C & B & A & A \\
\hline General Litter & e.g. bottles & B & B & B & B & B \\
\hline Harmful litter & $\begin{array}{l}\text { Broken } \\
\text { glass } \\
\text { Others }\end{array}$ & D & D & C & D & D \\
\hline Accumulations & Number & D & D & D & D & D \\
\hline Oil & & B & A & A & A & A \\
\hline Excrement & & C & D & C & C & D \\
\hline
\end{tabular}

Grading: A Very good; B Good; C Fair, D Poor

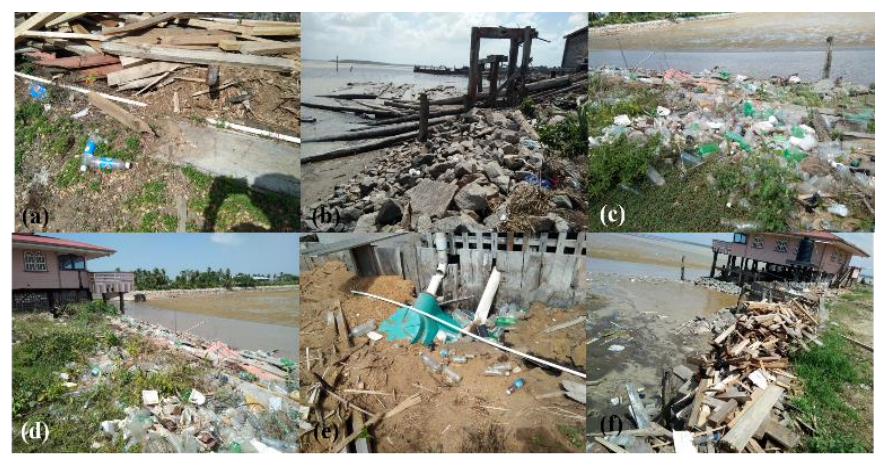

Figure 4: Sample litter area of Sample Site 1 showing the accumulation of wood fragments (a and f), wood logs (b), deposit of plastic bottles and general wastes (c and d). Overall Grading for this sample site is Litter Grade D. 
At Sample Site 2 in Corentyne, overall grading of the beach based on EA/NALG guide could be D (Table 4) [49]. However, it is important to highlight that with clean-up of the beach, the grade could be easily changed to C. This site is one of the 'quandaries of litter research' that do not fit into any universal methodology or guide [3]. However, the deposits of general wastes, unused and condemned wooden boats and its fragments, wood logs, dead fish, different kinds of clothing materials, organic deposits of fruits, general litter, cardboards, and other materials caused the beach to be graded "poor" in EA/NALG guide, (Table 4, Figure 5)[49].

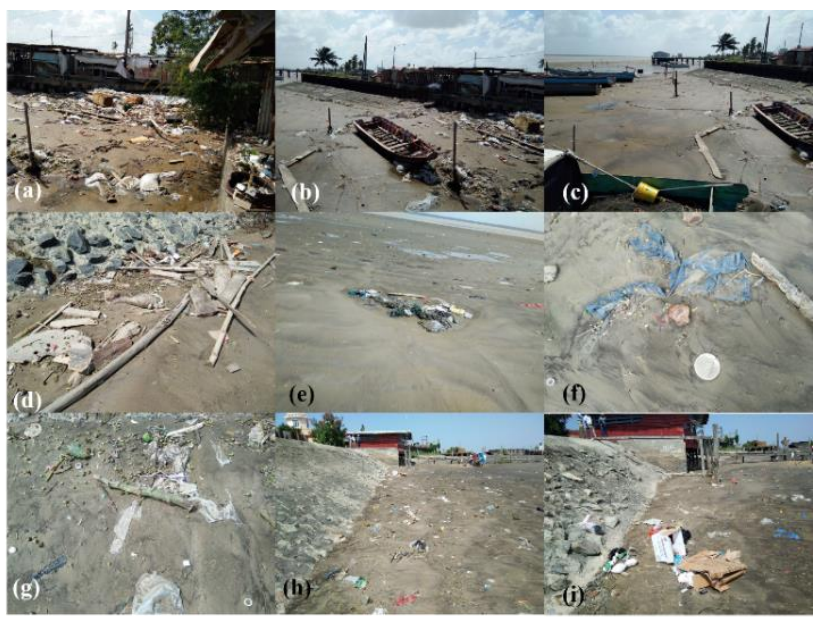

Figure 5: Examples of the Sample Site 2 showing the deposits of general wastes (a), unused and condemned wooden boats and its fragments (b and c), wood logs, dead fish (d), clothing materials (e and f), organic deposits of fruits, etc (g), general litter (h), and cardboards (j). Overall Grading for this sample site is Litter Grade D.

Sample Site 3 at Rosignol could be graded as a C (Figure 6, Table 4). Out of the five sampling sites, this site is the only one that requires minimal cleanup which could easily change the status of the litter grade to a B or an A. However, the presence of general waste, such as plastic water bottles, plastic cups, straws, and food package, has made this beach - which has the potential to develop into a spot for local and international recreational and tourism activities - to be classified as Grade C; fair (Figure 6).

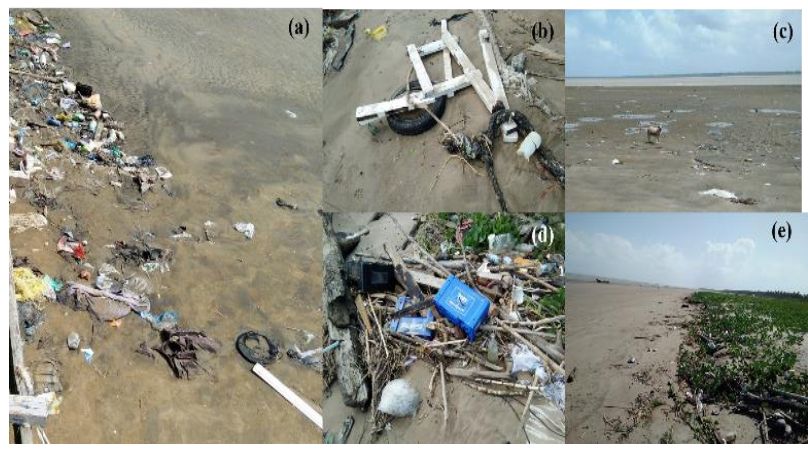

Figure 6: Examples of the Sample Site 3 showing the scattering of general wastes (a), wood fragments/abandoned tyres (b), stranded live animal (c), deposits of plastics and general litters (d), some organic and wood fragments (e). Overall Grading for this sample site is Litter Grade C.

With respect to the sampling sites for this study, sample Site 4 at Mahaicony was the smallest of the sites visited. It can be classified as a rural beach due to its location, and it is therefore frequented by the locals. Every inch of the available space in this site was grossly littered. Potential hazardous items which could be sub-categorised into cutting hazardous items (e.g. glass fragments, broken tin cans, and pieces of wood or metal with nails protruding) and infection hazardous items (e.g. dead animals/fishes, sanitary towels, other hygienic products (feminine), and nappies) were highly concentrated in the limited sandy space meant for recreational use (Figure 7). The presence and concentration of these forms of litter and other hazardous items and the fact that the site would need a comprehensive clean-up made this site to be classified as Grade D or very poor for recreational use and services.

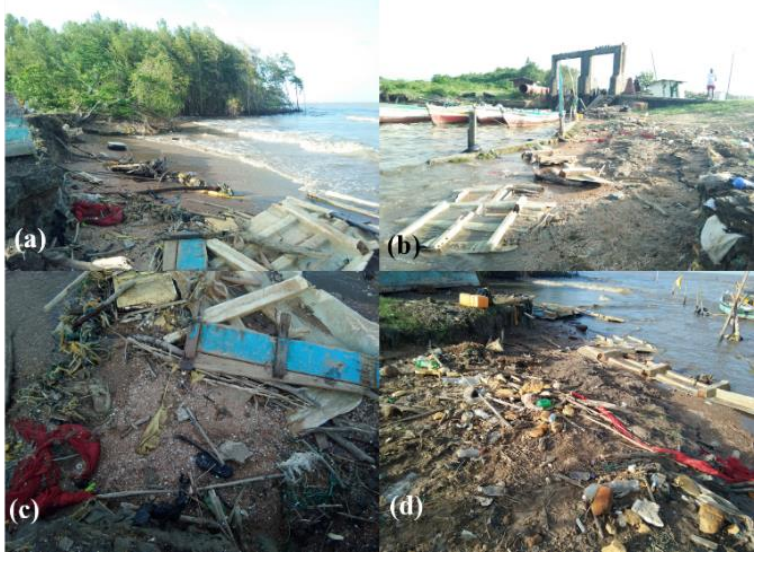

Figure 7: Examples of litter found at Sample Site 4. This shows accumulations of wood fragments and planks with nails protruding (a), inuse and abandoned canoes (b), deposit of general wastes (c and d). Overall Grading for this sample site is Litter Grade D.

Sample site 5 in Georgetown, the capital city, is an urban area and has a mixture of various litters. The materials could be classified as those found on a grade $\mathrm{A}$ beach, such as cotton buds, gross litters, and oil; grade B beach involving general litters; grade $C$ with general debris; and grade $D$ beach when ubiquitous harmful litter items, including broken glasses and accumulation of several other litter items are involved (Table 4). The beach litter numbers were immense, and they stretched along the shoreline (Figure 8). Plastics of all sorts, cloth, pieces of kites, cigarettes, and left-overs from beach parties, items of religious activities, drinking straws, plastic cups, food packaging, polystyrene, plates, and discarded shoes, among others were components of the litters at this site, and these 'litter flags' indicate the influence of beach users [65]. In addition to these forms of litter composition, the notable presence of harmful substances, for instance, broken glasses, and excrement accounted for grade D; poor for tourism purposes in its current state. However, the cleaning up does not have to do with heavy vehicles, and this could be executed within a relatively short time and therefore grade $\mathrm{C}$ can be easily assigned; fair for tourism and recreational use. Despite the ubiquitous presence of litters, the site is still being used for recreational activities. With regular clean-up efforts, it could be well developed into a category A beach and used for tourism purposes.

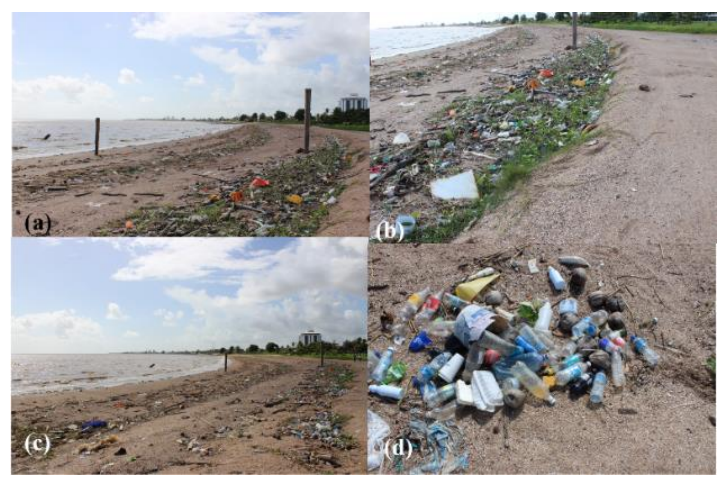

Figure 8: Examples of the sample litter area of Sample Site 5 showing the accumulation of general litters/sewage ( $a, b$ and $c)$, and deposit of plastic materials, food wastes, etc. (d). Overall Grading for this sample site is Litter Grade C.

In this study, it can be summarily stated that the beach users are the main depositors of litter at the sample sites and this is conversant with findings in other places $[3,6,17,35,66]$. Several factors could be responsible for this form of disposition. Among these are lack of good education, lack of consciousness of environmental responsibilities, and in all of the sample areas, lack of beach trash or litter container; some of which have also been documented in literatures [3]. Another potential source of litter in the beach area is river [35]. However, the carriage of litters from the hinterland to these samples sites is extremely limited. It suggests that solid litter pollution along the study sites is significantly related to the presence of people residing in nearby urban or rural communities. Indeed, landbased activities produce most of the litters found in coastal areas of the world, with the observation that there is an inverse relationship between the quantity of litters on beach and the geographic distance from the main population centres [67-71]. 
Therefore, the focus of improving the coastal scenic environment is the assessment and management of these beautiful beaches (e.g. Figure 9) that have been marred by human sewage and litter. These beaches could be upgraded to the next class. Some example of conscious actions to improve beach safety and beauty for Morocco are documented in Williams and Khattabi [66]. Cleaning up of the beaches, especially the sampled study sites, is one of the conscious actions that can be taken in managing the beach areas. However, dealing with the litter at the source of generation remains a potential force in curtailing the exponential growth of the litters at the coastal/beach areas [72]. In this study, plastics have a perennial presence in all the study sites. As mentioned by the researchers, conscious efforts must be made to reduce plastic usage. In fact, researchers have recommended the use of carbon neutral and biodegradable materials can be used as replacement [73]. Acknowledgement of this litter problem, determination of the sources of litters, constant and continuous monitoring of their trend and volume of occurrence along the beach areas, enforcement of the policy and laws against littering, engagement of industry, regional governments, regulatory authorities and wider public in an integrated management and disposal of litters at the source, improvement of waste management practices (through disposal or recycling), aggressive beach user education, engagement of cleaners and appropriate enforcement of the established code of beach usage are some of the conscious efforts that can be considered in managing the coastal areas for recreational and tourism purposes [3,5,74-77].

Figure 9 shows examples of some sections of the beaches at the study sites with limited litters. This suggests that beach areas can be utilised and developed to benefit from tourism activities. However, the litter issue is gravely threatening the coastal tourism industry in Guyana, and the conscious effective management plans for these sites should aim at challenging these threats. The surveys by Williams and Micallef [16] identified five (5) parameters that are of interest to coastal tourists. These are safety, facilities, water quality, litter, and scenery. This shows that litter threatens the economic potential of a beach and its tourism revenues [7881]. The incentives to benefit from, or cash in on, the growing coastal tourism industry in the Guyana should be a prime motivation to engage in the cleaning-up operation of these beach areas by the decision markers, coastal managers, planners or other appropriate administrative authorities.

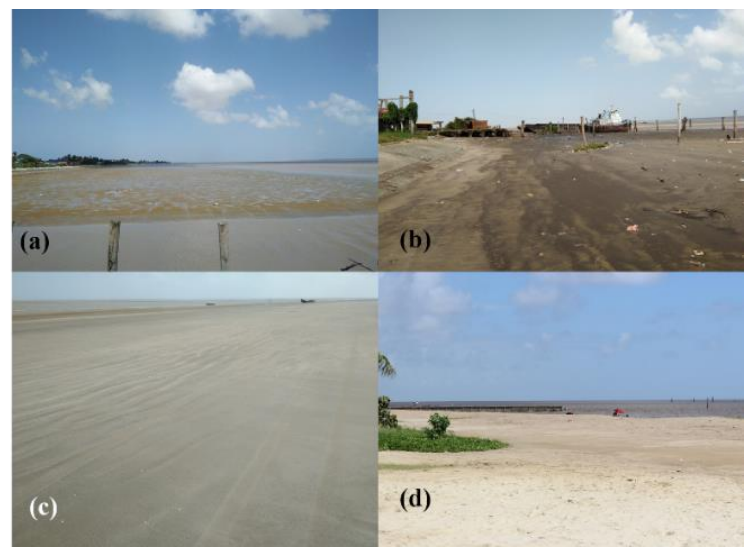

Figure 9: Examples of sections of the beaches with little or no litter (a) Sample Site 1, (b) Sample Site 2, (c) Sample Site 3 and (d) Sample Site 5, which show the great potential of their use for tourism/recreational activities.

\section{RECOMMENDATION, CONCLUSION AND OUTLOOK}

The limitless growing capacity of coastal tourism to the Caribbean coastal areas in reflected in the number of international travels between 2007 and 2015. However, five (5) factors remain of tremendous considerations by beach users and coastal tourists: 'safety, facilities, water quality, and presence/absence of litters and scenery'. The focus of this study is the composition of litters and its grading in five sampled locations along Guyana coastline. For litter composition, in all of the sampled sites, plastic materials had the highest litter make-up (48.2\%), followed by metals at $20.8 \%$, papers at $11.5 \%$, glass at $6.8 \%$, wood and wood fragments at $4.7 \%$, clothing materials at $4.6 \%$, materials of organic origin at $3.2 \%$ and pottery at $0.3 \%$ respectively. In terms of litter grading, none of the sample sites could be graded very good (A) or good (B) because of the presence of harmful litters and accumulation of other different types of wastes. Sample Sites 2 and 5 at No. 63 Beach and Georgetown are the only sites that could be graded fair (C) and have the potential of being upgraded if the clean-up of the litters could be carried out in improving the coastal scenery.
The presentation in this study has been geared towards identifying some factors that affect expanding coastal tourism in Guyana. Apart from the various ways of dealing with the sources of litter generation and the management practices identified in this study, other recommendations include:

- Aggressive plastic container recycling. This is highly recommended as plastic materials constitute the bulk of litter composition in these coastal areas;

- Consideration and establishment of Polymer Engineering programme and research facilities at the University of Guyana (UG) to support the manufacturing industries' efforts to use alternative materials;

- Concerted efforts should be directed to education and awareness of the importance of beaches

- Provision of incentives for recycling of plastic wastes, public and individual management of litters at the sources;

- Provision of incentives for recycling of plastic wastes;

- Exploration and application of Volunteered Geographic Information System [1] in Beach Litter Management and Monitoring would go a long way to assist in spatial monitoring of litters and waste along the coastline.

This study is an overview of the section of Guyana's coastline, highlighting the importance of beach cleanliness and the need to take practical actions for addressing beach littering and promoting the coastal tourism industry. Tourists want litter-free beaches and beautiful scenery. It is therefore highly essential to meet the demands of the potential beach users if the nation is to capitalize on the growing "sun, sea and sand (3S)" industry.

\section{ACKNOWLEDGEMENT}

The authors wish to thank Faculty of Earth and Environmental Sciences, University of Guyana for the financial support towards fieldwork. Dr Patrick Williams is specially appreciated for his support during the field survey and sampling.

\section{REFERENCES}

[1] Fatehian, S., Jelokhani-Niaraki, M., Kakroodi, A. A., Dero, Q. Y., Samany, N. N. 2018. A volunteered geographic information system for managing environmental pollution of coastal zones: A case study in Nowshahr, Iran. Ocean and Coastal Management 163, 54-65.

[2] Klein, Y.L., Osleeb, J.P., Viola, M.R. 2004. Tourism generated earnings in the coastal zone: a regional analysis. J. Coast. Res. 20 (4), 1080-1088.

[3] Williams, A. T., Rangel-Buitrago, N. G., Anfuso, G., Cervantes, O., Botero, M. C. 2016a. Litter impacts on scenery and tourism on the Colombian north Caribbean coast. Tourism Management 55, 209-224

[4] Houston, J. R. 2013. The economic value of beaches a 2013 update Shore and Beach, 81(1), 3-11.

[5] Williams, A.T., Randerson, P., Di Giacomo, C., Anfuso, G., Macias, A., Perales, J.A.,2016b. Distribution of beach litter along the coastline of C_adiz. Spain. Marine Pollution Bulletin, 107 (1), 77-87.

[6] Botero, C. M., Anfuso, G., Milanes, C., Cabrera, A., Casas, G., Pranzini, E., Williamsn, A. T. 2017. Litter assessment on 99 Cuban beaches: A baseline to identify sources of pollution and impacts for tourism and recreation. Marine Pollution Bulletin, 118, 437-441.

[7] ANATO - Asociaci_on Colombiana de Agencias de Viajes y Turismo. 2015. Compendio de estadísticas turísticas de ANATO 2015. Bogota: ANATO.

[8] BANREP - Banco de la Republica de Colombia. 2015. Boletín econ_omico regional para el II trimestre de 2015 en la Costa caribe Colombiana. Bogota, Banco de la Republica.

[9] Doods, R., Kelman, I., 2008. How climate change is considered in sustainable tourism policies: a case of the Mediterranean islands of Malta and Mallorca. Tour. Rev. Int. 12,57-70.

[10] UNWTO. 2015. “Tourism Highlights, 2015 Edition.” Madrid. 
[11]Benoit, G., and Comeau, A. 2005. A sustainable future for the Mediterranean, the blue plan's environment and development outlook. London: Earthscan.

\section{[12] UNWTO. 2016. “Tourism Highlights, 2016 Edition." Madrid.}

[13] Anfuso, G., Williams, A. T., Martínez, G. C., Botero, C. M., Cabrera Hernández, A.,Pranzini, E. 2017. Evaluation of the scenic value of 100 beaches in Cuba: Implications for coastal tourism management. Ocean and Coastal Management 142, 173-185.

[14] Anfuso, G., Williams, A. T., Cabrera Hern_andez, J. A. C., Pranzini, E. 2014. Coastal scenic assessment and tourism management in western Cubar Tourism Management,42, 307-320. http://dx.doi.org/10.1016/j.tourman.2013.12.001.

[15] Pranzini, E., Anfuso, G., Botero, C.-M., Cabrera, A., Apin Campos, Y., Casas Martinez, G.,Williams, A.T. 2016. Sand colour at Cuba and its influence on beach nourishment and management. Ocean Coastal Management http://dx.doi.org/10. 1016/j.ocecoaman. 2016.03.013.

[16] Williams, A.T., Micallef, A. 2009. Beach management: Principles and practices. London: Earthscan. http://dx.doi.org/10.1111/j.14754959.2010.00360_1.x.

[17] Rangel-Buitaro, N., Williams, A., Anfuso, G., Arias, M., Adriana Gracia, C. 2017. Magnitudes, sources, and management of beach litter along the Atlantico department coastline, Caribbean coast of Colombia. Ocean and Coastal Management 138, 142-157.

[18] Kusui, T., Noda, M. 2003. International survey on the distribution of stranded and buried litter on beaches along the Sea of Japan. Mar. Poll. Bull. 47, 175-179.

[19] Browne, M.A., Galloway, T.S., Thompson, R.C. 2010. Spatial patterns of plastic debris along estuarine shorelines. Environmental Science Technology. 44, 3404-3409.

[20] Poeta, G., Battisti, C., Acosta, A.T.R. 2014. Marine litter in Mediterranean sandy littorals: spatial distribution patterns along central Italy coastal dunes. Mar. Pollut. Bull. 89 (1-2), 168-173. http://dx.doi.org/10.1016/ j.marpolbul.2014.10.011.

[21] Schulz, M., Clemens, T., Förster, H., Harder, T., Fleet, D., Gaus, S., Grave, C., Flegel, I., Schrey, E., Hartwig, E. 2015. Statistical analyses of the results of 25 years of beach litter surveys on the south-eastern North Sea coast. Marine Environment Resources. 109,21-27. http://dx.doi.org/10.1016/j.marenvres.2015.04.007.

[22] Moore, C.J., Lattin, G.L., Zellers, A.F. 2011. Quantity and type of plastic debris flowing from two urban rivers to coastal waters and beaches of Southern California. J. Integrated Coastal Zone Manage. 11, 65-73.

[23] Oliveira, F., Monteiro, P., Bentes, L., Henriques, N.S., Aguilar, R., Gonçalves, J.M.S. 2015. Marine litter in the upper São Vicente submarine canyon (SW Portugal): abundance, distribution, composition and fauna interactions. Marine Pollution Bulletin, 97 (1-2), 401-407. http://dx.doi.org/10.1016/j.marpolbul.2015.05.060.

[24] Zhou, C., Liu, X., Wang, Z., Yang, T., Shi, L., Wang, L., Cong, L., Liu, X., Yang, J. .2015. Marine debris surveys on four beaches in Rizhao City of China. Glob. Journal of Environmental Science and Management 1 (4),305314. http://dx.doi.org/10.7508/gjesm.2015.04.005.

[25] Slavin, C., Grage, A., Campbell, M. L. 2012. Linking social drivers of marine debris with actual marine debris on beaches. Marine Pollution Bulletin, 64:

http://dx.doi.org/10.1016/j.marpolbul.2012.05.018.

[26] Campbell, M. L., Slavin, C., Grage, A., Kinslow, A. 2016. Human health impacts from litter on beaches and associated perceptions: a case study of 'Clean' Tasmanian beaches. Ocean Coastal Management 126,22-30. DOI: 10.1016/j.ocecoaman.2016.04.002.

[27] Wace, N. 1994. Beachcombing for ocean litter. Aust. Nat. Hist. 24, $46 \mathrm{e} 52$.
[28] Tudor, D., Williams, A.T., 2002. The use of multivariate statistical techniques to establish beach debris pollution sources. J. Coast. Res. 36, 716-725.

[29] Williams, A.T., Tudor, D., Randerson, P. 2003. Beach litter sourcing in the Bristol channel and Wales, UK. Water, Air, Soil Pollution 143 (1e4), 387-408.

[30] Carson, H.S., Lamson, M.R., Nakashima, D., Toloumu, D., Hafner, J., Maximenko, N.,McDermid, K.J. 2013. Tracking the sources and sinks of local marine debris in Hawai'i. Marine Environment Resources. 84, 76-83.

[31] Bravo, M., de los Ángeles Gallardo, M., Luna-Jorquera, G., Núñez, P., Vásquez, N., Thiel, M. 2009. Anthropogenic debris on beaches in the SE Pacific . Chile: Results from a national survey supported by volunteers. Marine Pollution Bulletin, 58, 1718-1726.

[32] Williams, A.T., Randerson, R., Alharbi, O. 2014. From a Millennium base line to 2012:beach litter changes in Wales. Marine Pollution Bulletin, $84,17-26$.

[33] Jones, M.M. 1995. Fishing debris in the Australian marine environment. Marine Pollution. Bulletin. 30, 25-33.

[34] CBD Technical Series, Secretariat of the Convention on Biological Diversity and the Scientific and Technical Advisory Panel-GEF, 2012 Impacts of Marine Debris on Biodiversity: Current Status and Potential Solutions, p. 61. Montreal, Technical Series No. 67.

[35] Laglbauer, B.J.L., Franco-Santos, R.M., Andreu-Cazenave, M., Brunelli, L., Papadatou, M., Palatinus, A., Grego, M., Deprez, T. 2014. Macrodebris and microplastics from beaches in Slovenia. Marine Pollution Bulletin, 89 (1-2),356-366. http://dx.doi.org/10.1016/j.marpolbul.2014.09.036.

[36] Poeta, G., Conti, L., Malavasi, M., Battisti, C., Rosario Acosta, A. T. 2016. Beach litter occurrence in sandy littorals: The potential role of urban areas, rivers and beach users in central Italy. Estuarine, Coastal and Shelf Science 181, 231-237.

[36]Schulz, M., Matthies, M., 2014. Artificial neural networks for modelling time series of beach litter in the southern North Sea. Mar. Environ. Res. 98: 14-20. http:// dx.doi.org/10.1016/j.marenvres.2014.03.014.

[37] Gago, J., Lahuerta, F., Antelo, P., 2014. Characteristics (abundance, type and origin) of beach litter on the Galician coast (NW Spain) from 2001 to 2010. Scentia Mar. 78 (1), 125-134.

[38] Araùjo, M.C.B., Sarah, M.S., Rufener, M.C., Aires, C.F., Santiago, A.S. 2011. Garbage on Natal Beaches (RN): Identification and Analysis of Key Sources. XIV Latin American Congress of Marine Sciences (Santa Catarina).

[39] Government of Guyana, GoG, 2012. Guyana's Second National Communication to the United Nations Framework Convention on Climate Change, Georgetown, Guyana, 186.

[40] Daniel, J. R. K .1988. Sea defence strategies and their impact on a coast subject to a cyclic pattern of erosion and accretion, Ocean and Shoreline Management, 11, 159 - 175.

[41] Van Ledden M, Vaughn G, Lansen J, Wiersma F, Amsterdam M .2009. Extreme wave event along the Guyana coastline in October 2005. Continental Shelf Research, 29, $352-361$.

[42] Environmental Protection Agency, 2002. Integrated Coastal Zone Management Action Plan- Guyana. www.un.org/esa/agenda21/natlinfo/wssd/ guyana.pdf.

[43] Augustinus, P. G. E. F. 2004. The influence of the trade winds on the coastal development of the Guianas at various scale levels, a synthesis. Mar. Geol. 208, 141-151.

[44] Anthony JE, Gardel A, Gratiot N, Proisy C, Allison MA, Dolique F, Fromard F. 2010. The Amazon-influenced muddy coast of South America: A review of mud-bank-shoreline interactions. Earth-Science Reviews, 103, $99-121$. 
[45] Gratiot N, Gardel A, Anthony EJ .2011. Trade-wind waves and mud dynamics on the French Guiana coast, South America: input from ERA-40 wave data and field investigations. Mar. Geol. 236 (1-2), 15-26.

[46] Flores CP, Muñoz JMB, Scherer MEG .2017. Management of transboundary estuaries in Latin America and the Caribbean. Marine Policy, 76: 63-70.

[47] NEDECO (Netherlands' Engineering Consultants). 1972. Reports on sea defence studies. Netherlands Engineering Consultants, The Hague, The Netherlands 1972.

[48] Winterwerp, J.C., de Graaff RF, Groeneweg J, Luijendijk AP .2007. Modelling of wave damping at Guyana mud coast. Coastal Engineering 54 (3), 249-261.

[49] EA/NALG. 2000. Environment Agency and the National Aquatic Litter Group. Assessment of Aesthetic Quality of Coastal and Bathing Beaches. Monitoring Protocol and Classification Scheme (15 pp.).

[50] Tudor, D.T., Williams, A.T. 2001. Transect size and other threshold levels in beach litter measurement. Shore Beach 69 (4), 13-18.

[51] Dixon, T., Dixon, T. 1981. Marine litter surveillance. Marine Pollution Bulletin, 12 (9), 289-295.

[52] Ribic, C.A. 1998. Use of indicator items to monitor marine debris on a New Jersey beach from 1991-1996. Marine Pollution Bulletin, 36 (11), 887-891.

[53] Jurado, V., Castro, M., Corral, C., Ruiz, C., Lara, R., Acosta, J., Macías, A., Gracia, J. 2006. Cuidemos la Costa 2004-2005. Red Coast Watch, Sevilla: Consejerías de Medio Ambiente y Educación, Junta de Andalucía (64pp).

[54] Cheshire, A.C., Adler, E., Barbi_ere, J., Cohen, Y., Evans, S., Jarayabhand, S., Jeftic, L.Jung, R.T., Kinsey, S., Kusui, E.T., Lavine, I., Manyara, P., Oosterbaan, L., Pereira, M.A., Sheavly, S., Tkalin, A., Varadarajan, S., Wenneker, B., Westphalen, G. 2009. UNEP/IOC Guidelines on Survey and Monitoring of Marine Litter. UNEP Regional Seas Reports and Studies. No. 186, IOC Technical Series No. 83, xii p 120.

[55] OSPAR 2009. Marine Litter in the North-East Atlantic Region: Assessment and Priorities for Response. OSPAR, London.

[56] NOAA Marine Debris Shoreline Survey Field Guide. 2012. Sarah Opfer, Courtney Arthur,and Sherry Lippiatt (19 pp.)

[57] Galgani, F., Hanke, G., Werner, S., Oosterbaan, L., Nilsson, P., Fleet, D., McKinsey, S., Thompson, R., VanFraneker, J., Vlachogianni, T., Scoullos, M., Mira Veiga, J., Palatinus, A., Matiddi, M., Maes, T., Korpinen, S., Budziak, A., Leslie, H., Gago, J.,Liebezeit, G. 2013. MSFD Technical Group on Marine Litter, Guidance on Monitoring of Marine Litter in European Seas. JRC Scientific and Policy Reports, SJRC83985, EUR 26113 ENI, SBN 978-92-7932709-4. http://dx.doi.org/10.27899475, 128. ISSN: 1831-9424.

[58] Zhou, P., Huang, C., Fang, H., Cai, W., Li, D., Li, X., Yu, H. 2011. The abundance composition and sources of marine debris in coastal seawaters or beaches around the northern South China Sea (China). Marine Pollution Bulletin, 62, 1998- 2007.

[59] Thiel, M., Hinojosa, I.A., Miranda, L., Pantoja, J.F., Rivadeneira, M.M., Vásquez, N. 2013. Anthropogenic marine debris in the coastal environment: A multi-year comparison between coastal waters and local shores. Marine Pollution Bulletin, 71, 307-316.

[60] Lozoya, J.P., Texeira de Mello, F., Carrizo, D., Weinsten, F., Olivera, Y., Cedres, F., Pereira, M., Fossati, M. 2016. Plastics and microplastics on recreational beaches in Punta del Este (Uruguay): unseen critical residents? Environment Pollution 218, 931-941.

[61] Rech, S., Macaya-Caquilpán, V., Pantoja, J. F., Rivadeneira, M. M., Jofre Madariaga, D., Thiel, M. 2014. Rivers as a source of marine litter - A study from the SE Pacific. Marine Pollution Bulletin, 82: 66-75.

[62] Williams, A. T., Simmons, S. L. 1997. Movement patterns of riverine litter. Water,Air and Soil Pollution, 98, 119e139. http://dx.doi.org/10.1007/BF02128653.
[63] Woodall, P.F. 1993. Marine litter on the beaches of Deepwater National Park, central Queensland. QId. Nat. 32, 72-75.

[64] Whiting, S. 1998. types and sources of marine debris in Fog Bay, Northern Australia. Marine Pollution Bulletin, 36 (11), 904-910.

[65] Silva, J., Scheyla, C. T., Barbosa de Araujo, M. C., Costa, M. F. 2008 Flag items as a tool for monitoring solid wastes from users on urban beaches. Journal of Coastal Research, 24(4), 890-898. http://dx.doi.org/10.2112/06-0695.1

[66] Williams, A. T., Khattabi, A. 2015. Beach scenery at Nador Province, Morocco.

[67] Galil, B.S., Golik, A., Türkay, M. 1995. Litter at the bottom of the sea: a sea bed survey in the Eastern Mediterranean. Marine Pollution Bulletin 30 (1), 22-24.

[68] Stefatos, A., Charalampakis, M., Papatheodorou, G., Ferentinos, G. 1999. Marine debris on the seafloor of the Mediterranean Sea: examples from two enclosed gulfs in Western Greece. Mar. Pollut. Bull. 38 (5), 389393.

[69] Aliani, S., Griffa, A., Molcard, A. 2003. Floating debris in the ligurian sea, northwestern mediterranean. Marine Pollution Bulletin, 46, 1142 1149

[70] Katsanevakis, S., Katsarou, A. 2004. Influences on the distribution of marine debris on the seafloor of shallow coastal areas in Greece (Eastern Mediterranean). Water Air Soil Pollution 159, 325-337.

[71] Gabrielides, G., Golik, A., Loizides, L., Marino, M., Bingel, F., Torregrossa, M. 1991. Man-made garbage pollution on the Mediterranean coastline. Marine Pollution Bulletin, 23, 437-441. http://dx.doi.org/10.1016/0025-326X(91)90713-3.

[72] Barnes, D.K.A. 2002. Invasions by marine life on plastic debris. Nature 416, 808-809.

[73] Williams, A.T., Pond, K., Ergin, A., Cullis, M.J. 2013. The hazards of beach litter. In: Finkl, C. (Ed.), Coastal Hazards. Springer, pp. 753-780.

[74] Morgan, R., Jones, T. C., Williams, A. T. 1993. Opinions and perceptions of England and Wales Heritage Coast beach users: some management implications from the Glamorgan heritage coast, Wales. Journal of Coastal Research, 9(4), 1083-1093.

[75] House, M., Herring, M. 1995. Aesthetic pollution: Public perception survey. Marlow: Foundation for Water Research.

[76] Williams, A. T., Nelson, C. 1997. The public perception of beach debris. Shore and Beach, 25, 17-20.

[77] Vaz, B., Williams, A. T., Pereira da Silva, C. P., Phillips, M. R. 2009 The importance of beach users' perception for beach management. Journal of Coastal Research,56, 1164-1168.

[78] Windom, H. L. 1992. Contamination of the marine environment from land based sources. Marine Pollution Bulletin, 25(1-4), 32-36. http://dx.doi.org/10.1016/ 0025-326X(92)90180-E.

[79] Williams, A.T., Pond, K., Phillipp, R. 2000. Aesthetic aspects, Ch. 12. In: Bartram, J, Rees, G. (Eds.), Monitoring bathing waters. E and F N Spon, London, Oxon, England, UK, p. 283-231

[80] Sheavly, S. B., Register, K. M. 2007. Marine debris and plastics: environmental concerns, sources, impacts and solutions. Journal of Polymer and the Environment,15, 301-305. http://dx.doi.org/10.1007/s10924-007-0074-3.

[81] Wyles, K. J., Pahl, S., Thomas, K., Thompson, R. C. 2015. Factors that can undermine the psychological benefits of coastal environments: exploring the effect of tidal state, presence, and type of litter. Environment and Behaviour, 40,1-32. 